\title{
CURRENT TREND IN THE FISCAL DEFICIT OF THE UNION BUDGET IN INDIA
}

\author{
MUDASIR AHMAD GANAI* \\ Dr. P. NALRAJ*** \\ * Ph.D Research Scholar, Department of Economics, Annamalai University \\ **Associate Professor, Department of Economics, Annamalai University
}

\begin{abstract}
The present study analyze the fiscal deficit as an instrument to measure the amount of government borrowing to require the financial position and their budget shortfall. This study traces the major current changes in Indian fiscal system during the period 2019-20, though the unions Government adopt the fiscal rule for reduction the financial crisis during the epidemic period of Covid-19. However the current study also traces the percentage of GDP decrease because of the problem of lockdown during the Covid-19. The paper concludes with discussion on the composition of union government receipts and expenditureposition in present scenario and indicated the situation of fiscal and revenue deficit of the government budget.
\end{abstract}

Keywords: Government Budget, Fiscal and Revenue Deficit, GDP, Fiscal Policy, Covid-19.

\section{INTRODUCTION}

Fiscal Deficit is one of the commondrawbacks of the budget in India. This term is broadly study the strength the financial position in union Government in India. But the present scenario fiscal deficit imbalanced the budgetary position in India. It is very important instrument used to measuring the union budgetary position ${ }^{[1]}$.

\subsection{CONCEPT OF FISCAL POLICYIN INDIA}

Post-independence in India's annual budgetary process has followed five year plans for ensuring long-term economic objectives. This process was under the control of planning commission, but there is no specific provision in the constitution. The plan component has a long term socio economic goals as determined by the ongoing plan process. Non-plan expenditure is based on the government expenditure for administration, salaries, defence, pension etc. Initially fiscal policy was deriving the development and also sharp progress of budget position in 1980 results the balanced of payment crisis of 1991. After that public debt situation again seemed to head towards unsustainable level around 2000, but India government adopted a new fiscal deficit discipline framework was intrude in 2003, when the parliament passed the Fiscal rule.In terms of tax policy both direct taxes and indirect taxes were focused on increasing revenue from the private sector to fund the public sector and achieve redistributive goals. In 1950-51 near about 
$6.3 \%$ ratio of GDP was estimated the union government of India. In 1987 - 88 the GDP was recorded to $4.1 \% .{ }^{[2]}$ But in current scenario India adopted the post economic reform that is LPG. After that union government also used fiscal rule policy for improving the condition of Gross Domestic Product in India. The present paper is based on the analyze the current situation Domistic Product, period from 2015- 2020 which is illustration in below table 1.

Table-1.

Percentage of GDP in India (2015-2020)

\begin{tabular}{|l|l|}
\hline Year & \% of GDP \\
\hline 2015 & $7.3 \%$ \\
\hline 2016 & $7.6 \%$ \\
\hline 2017 & $7.6 \%$ \\
\hline 2018 & $6.7 \%$ \\
\hline 2019 & $6.7 \%$ \\
\hline 2020 & $4.9 \%$ \\
\hline
\end{tabular}

\section{Source: www.indexmudi.com}

The above table- 1 indicates the variation of percentage of GDP from 2015 to 2020 . The percentage of GDP rise from $7.3 \%$ in 2015 to $7.6 \%$ in 2016 and was same to $7.6 \%$ in 2017 . The percentage also rises to $6.7 \%$ in 2018. But the percentage of GDP decreases to $4.9 \%$ in 19 due to the financial crisis problem of covide-19. ${ }^{[3]}$

\subsection{MEANING AND CONCEPT OF DEFICIT FINANCING}

When the government expenditure more as compare to government earn earn (receipts), in this situation called as fiscal deficit. It is used for measure the indebtedness of the government and deficit situation as well. It also measuring governments market borrowing and liabilities under taking. ${ }^{[4]}$

FISCAL DEFICIT: It refers that budgetary situation in which Government total expenditure (Revenue + Capital expenditure) is more than total Receipts (Revenue + Capital Receipts). But it can be symbolically speaking

$$
\mathrm{FD}=\mathrm{TE}-\mathrm{TR} \text { and other than borrowings. }
$$

Fiscal deficit have also main two branches as follows

GROSS FISCAL DEFICIT: It is that deficit situation in which aggregate expenditure, including net domestic leading and revenue receipts minus the grants. But it can be understand through mathematical equation:

G F D = Revenue + Capital Expenditure + Net Domestic Leading - Revenue Receipts - Grants.

NET FISCAL DEFICIT: In this situation Gross Fiscal Deficit is more than Net Domestic Lending thus

$$
\text { NFD = GFD }- \text { NDL }
$$

BUDGET DEFICIT: Budget Deficit is that budget situation in which Government budget expenditure minus budget receipts. It can be mathematically interpreted as.

$$
\mathrm{RD}=\mathrm{BE}-\mathrm{BR} \text {. }
$$


REVENUE DEFICIT: It is that budgetary situation in which Revenue Expenditure is more than Revenue Receipts. It can be best understand through mathematical equation.

$$
\mathrm{RD}=\mathrm{RE}-\mathrm{RR}(\mathrm{RE}>\mathrm{RR})
$$

Primary Deficit: It is equal to Fiscal Deficit minus Interest Payment. ${ }^{[5]}$

\section{OBJECTIVES}

To study the analysis of various trends of the government of India to covering the deficit financing in current scenario and also highlights the events of 2019-20, covering the new or current situation of the union budget. The present also analysis the composition of budget estimation from 2015-16 to 2019-2020. ${ }^{[6]}$

\section{METHODOLOGY}

To analysis the trends of deficit finance in India union budget likewise budget deficit, primary deficit, fiscal and revenue deficit as per estimation of GDP has been analysis by using time series secondary data. This analysis is based on secondary data which is collected from secondary sources like Statistics handbook on Indian economy (2018-19), Reserve Bank India andEconomy survey in India ${ }^{[7]}$

Further the study analyses the fiscal deficit and percentage share of components of budget with total expenditure and total receipts. ${ }^{[8]}$

\section{CURRENT FISCAL SITUATION IN INDIA}

On the basis current budgetary position in India first in 2003 India adopted the fiscal responsibility rule in order to improve the condition of fiscal discipline. Under this Act government of India targeting and aiming to achieve $3.0 \%$ deficit in 2020-21. But in 2019-20, it stood at $3.7 \%$ significantly above the 3\% target. In 2008 there is one global crisis (GFC). As for as this scenario the fiscal deficit packed at $6.6 \%$ during this period. After that we can noticed that the fiscal deficit should be reduced in each successive year. But suddenly one of the problem took place i.e. Covid-19 lockdown, that is one of the most drawback of the indian economy to reduce the Gross Domestic Product. ${ }^{[9]}$ But this paper analysis is interpreted through the schedules, graphs and charts.

Table-2.

Percentage of gross, revenue and primary deficit of union government of India from 2015- 16 to 2019-20

\begin{tabular}{|c|c|c|c|}
\hline Year & $\begin{array}{c}\text { Gross fiscal } \\
\text { Deficit }\end{array}$ & $\begin{array}{c}\text { Revenue } \\
\text { Deficit }\end{array}$ & $\begin{array}{c}\text { Gross Primary } \\
\text { Deficit }\end{array}$ \\
\hline $2015-16$ & 3.87 & 2.49 & 0.66 \\
\hline $2016-17$ & 3.49 & 2.06 & 0.36 \\
\hline $2017-18$ & 3.46 & 2.59 & 0.36 \\
\hline $2018-19$ & 3.34 & 2.16 & 0.25 \\
\hline $2019-20$ & 3.34 & 2.3 & 0.21 \\
\hline
\end{tabular}


Source: Select Fiscal Indicators of the Central Government, (As percentage of GDP), Handbook of Statistics on Indian Economy 2018-19 and Reserve Bank of India.

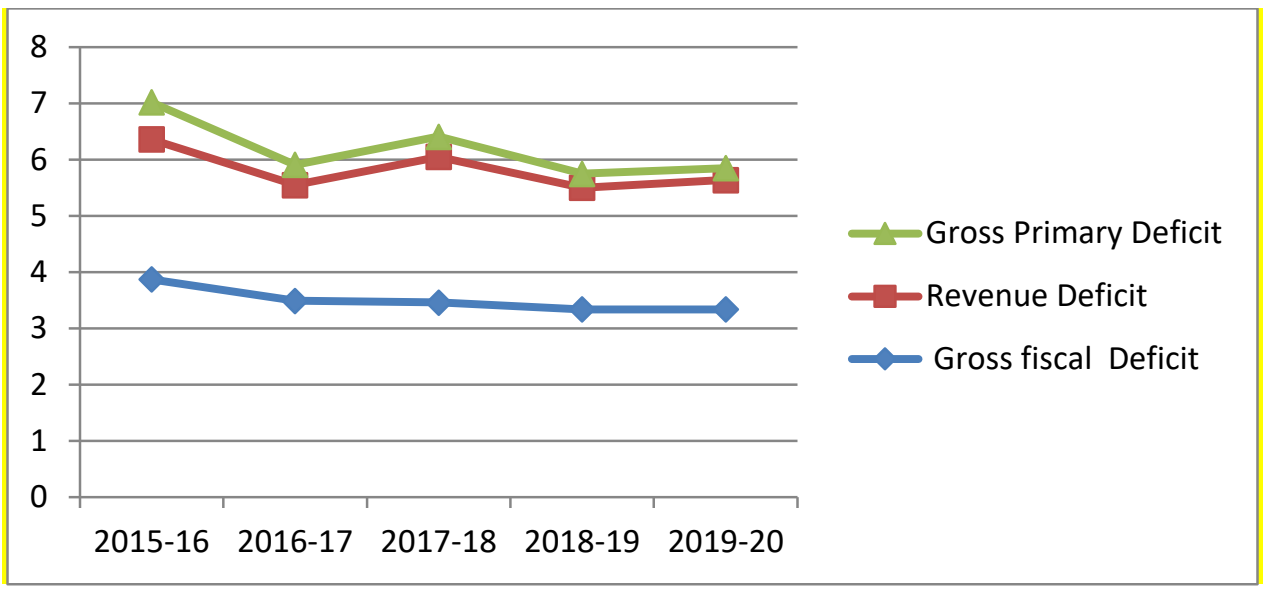

Figure- 1

From the period 2015-16 to 2019-20, the contribution defence, interest payment and subsidies, as percentage of Revenue Expenditure rose to $29 \%, 10 \%$ and $17 \%$ in $2015-16$. Which can be illustrating through pie-chart?

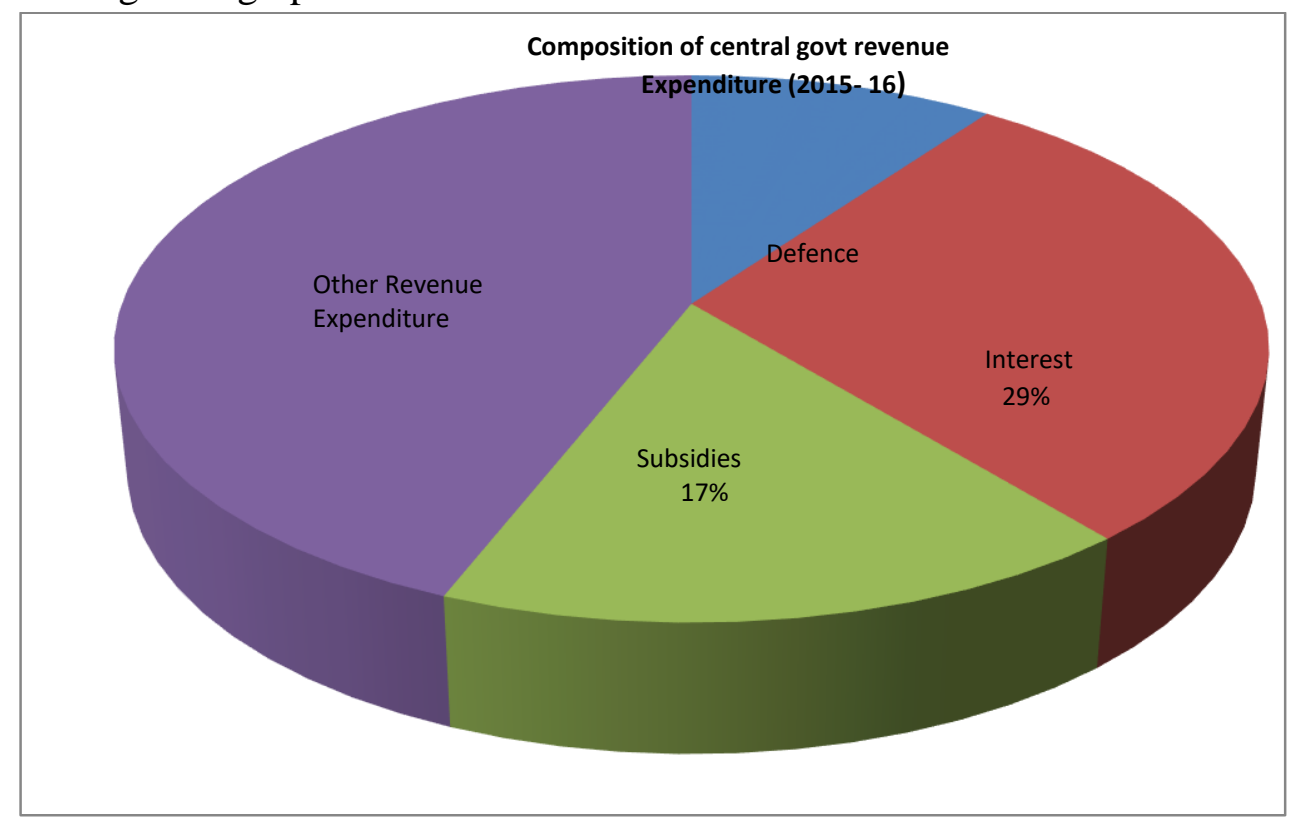

Figure 2

Source: Author's Calculation by using database from Table 1 .

From the same contribution of Defence, subsidies and interest payment decline to $8 \%, 27 \%$ and $14 \%$ in (2019-20) respectively. This can be also illustrating through pie-chart. 


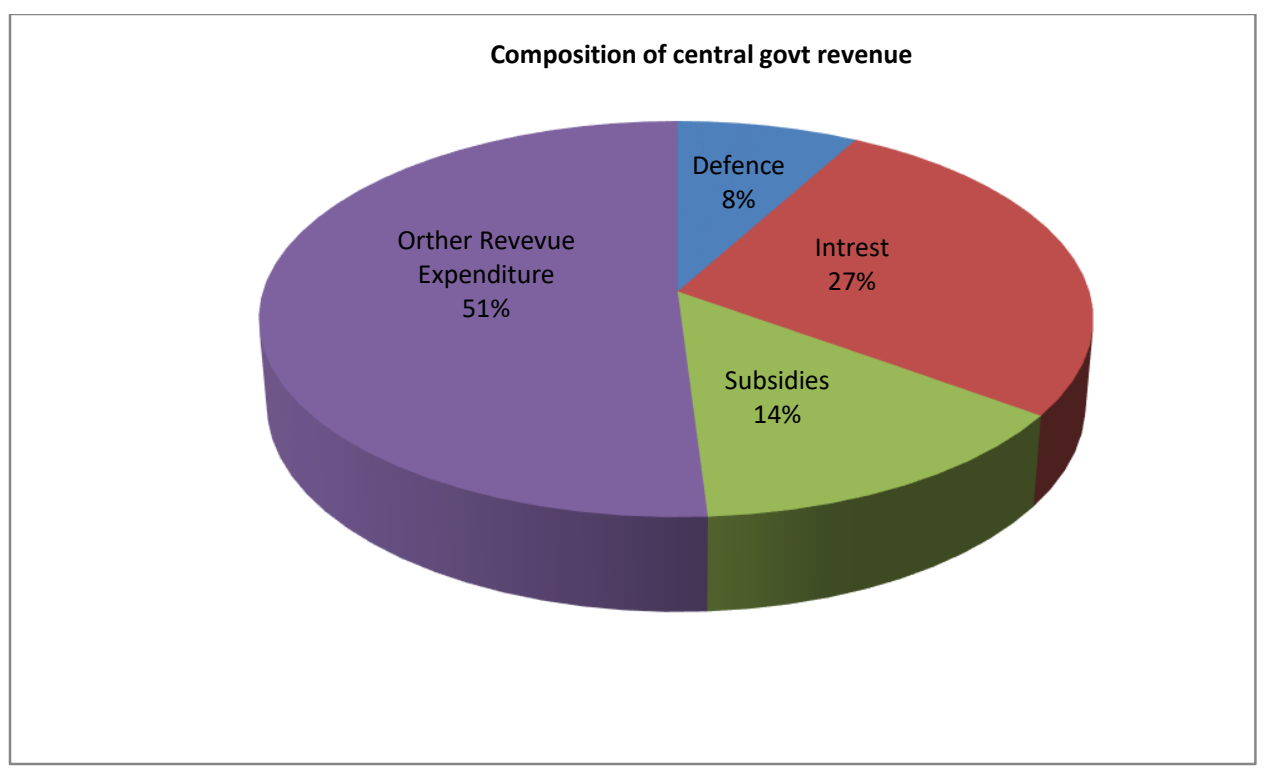

Figure 3

Source: Author's Calculation by using database from Table 1 .

This paper also used for check the percentage composition of Revenue Receipts of union government in India during the current period 2015-16 to 2019-20 which can be interpreted through pie- chart.

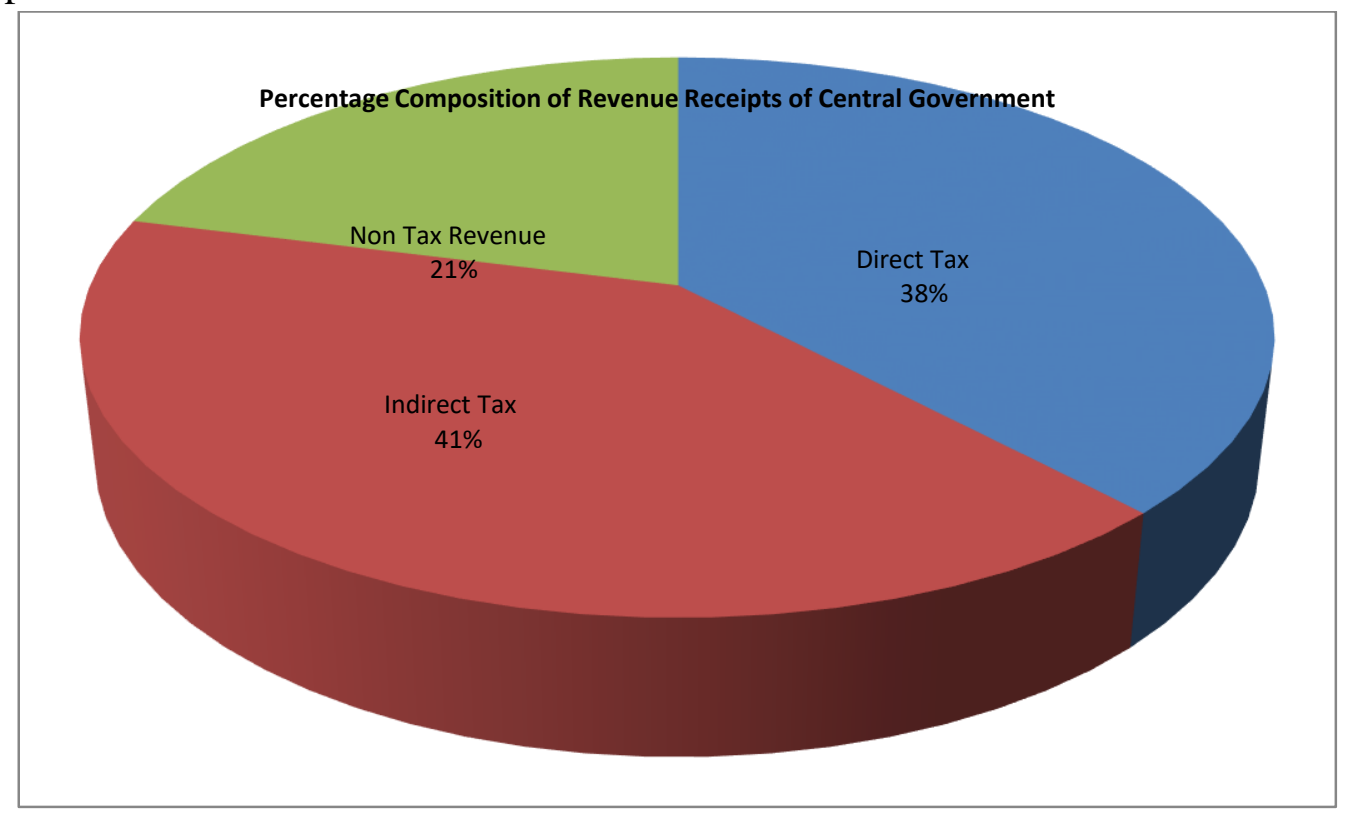

Figure 4

Source: Author's Calculation by using database from Table 1 


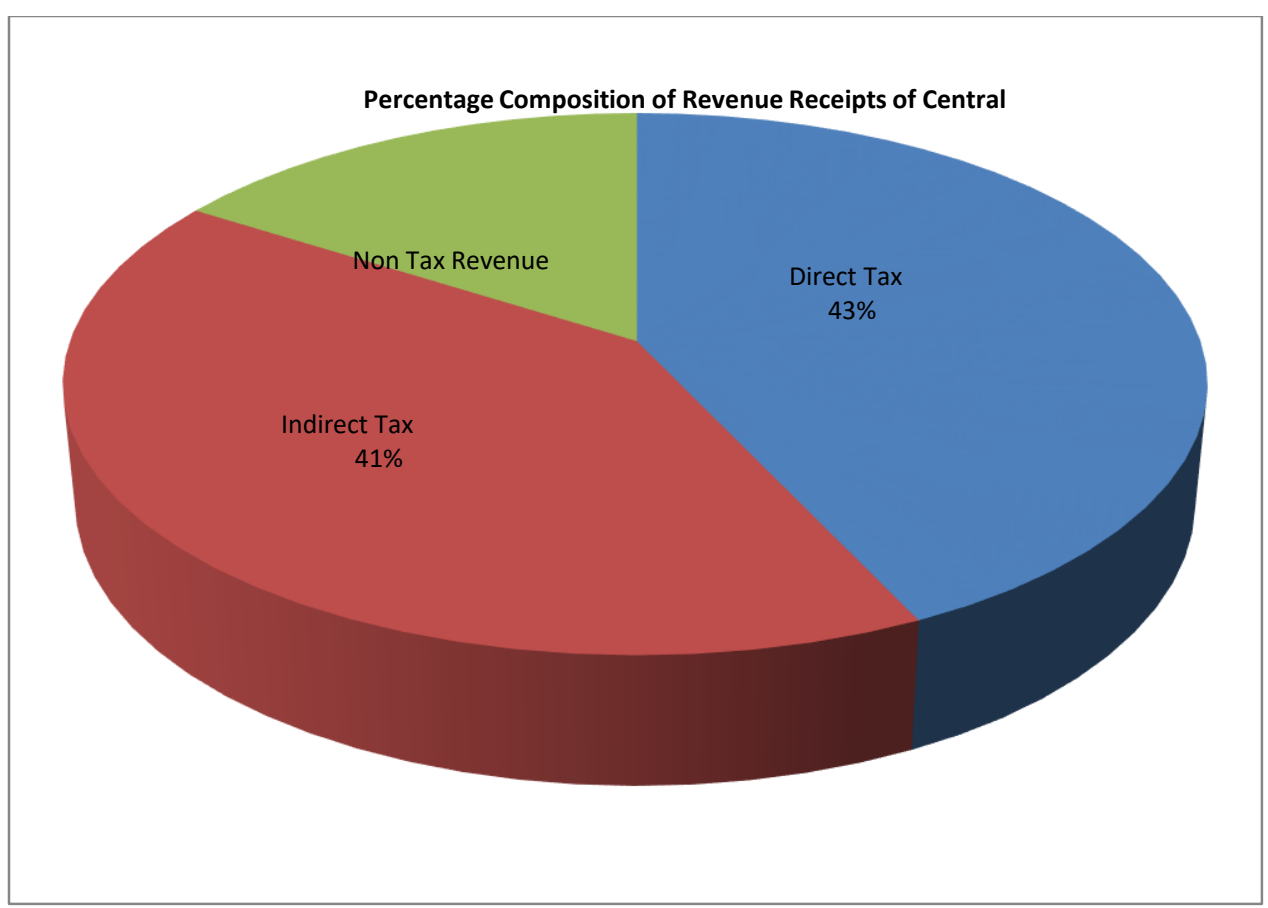

Figure 5

Source: Author's Calculation by using database from Table 1.

\section{FISCAL SITUATION OF INDIA IN COVID- 19}

Actually Covid-19 is a pandemic or health crisis, this crisis has rattled the world economy. In India government has promote the 1.7 trillion fiscal packages to control the pandemic crisis. Under this situation, fiscal policy can provides relief to those most impacted by the shutdown. In some its full potential. ${ }^{[10]}$

As for as concerned the deficit situation in post Covid-19 is measured to spread the pandemic will impact the fiscal deficit situation has been divided into two channels were as first is allocation of sizable portion of their budget to fight the pandemic which include expenditure on health and social security. Second part include the enforced lockdown and containment measure will lead to full in economy activity and it will be also lead to a fall in GDP as well as tax collection. So that it will be check the expenditure go up, but the tax receipts will also go down. As in same case in GDP go to the down word direction and deficit exceed because of due to pandemic global crisis Covid-19. ${ }^{[11]}$

\section{CONCLUSION}

Overall during 2015- 16 to 2019- 20, it seen that the Periods of Financial Problems and also the latest the problems and of lockdowns due to pandemic covid-19. But the union government led to take steps to promote to introduce and adopt economic reform and use the fiscal to ensure that the Fiscal Deficit stood at more reasonable level. However since 2015- 16 Union Government has under taken fiscal policy for the purpose to reduce fiscal deficit and also adopt the fiscal policy to exceed the percentage of GDP leading to more resilient economy. ${ }^{\text {[12] }}$ 


\section{REFERENCES}

1) Khan, M. (2003). Problem of Fiscal condition in Union Finances (Doctoral dissertation, Aligarh Muslim University).

2) Lee, C., \& Chew-Ging, L. (2017). The evolution of development planning in Malaysia. Journal of Southeast Asian Economies, 436-461.

3) Kolte, A., et al., (2019). Critical situation of Indian economic reforms of 1991: a lesson for developing economies. International Journal of Engineering and Advanced Technology, 8(5S3), 490-500.

4) Bifulco, R., et al., (2012). Debt and deception, states avoid making hard fiscal decisions. Public Administration Review, 72(5), 659-667.

5) Chakraborty, P., \& Dash, B. B. (2017). Fiscal reforms, fiscal rule, and development spending: How Indian states have performed?. Public Budgeting \& Finance, 37(4), 111-133.

6) Singh, C., et al., (2017). A Review of the FRBM Act. IIM Bangalore Research Paper, (550).

7) Trivedi, P., et al., (2019). Government Deficit Crowd Out Private Investment? An Empirical Analysis for National and Sub-National Governments. IUP Journal of Applied Economics, 18(3), 7-36.

8) Mohanty, R. K. (2012). Deficit-economic growth nexus in India: A cointegration analysis. New Delhi: Centre for Economic Studies \& Planning, School of Social Sciences Jawaharlal Nehru University.

9) Sucharita, S., \& Sethi, N. (2011). Fiscal discipline in India. Romanian Journal of Fiscal Policy (RJFP), 2(1), 1-23.

10) Balajee, A., et al., (2020). Fiscal Situation of India in the Time of COVID-19. Indian School of Business.

11) Dev., S. M., \& Sengupta, R. (2020). Covid-19: Impact on the Indian economy. Indira Gandhi Institute of Development Research, Mumbai April.

12) Singh, M. K., \&Neog, Y. (2020). Contagion effect of COVID-19 outbreak: Another recipe for disaster on Indian economy. Journal of Public Affairs, 20(4), e2171. 